\title{
INDO-ARYAN VERNACULARS
}

(Continued.)

By Sir Georae Grierson, K.C.I.E.

Chapter II: Historical

47. We have completed our geographical survey of the IndoAryan Vernacular and their dialects. It has been seen that they have been divided into three families, a Midland, an Intermediate, and an Outer. We shall now consider the mutual relationship of these families, and it will be more convenient to consider their growth downwards from the source than to follow their course upstream. The treatment must necessarily be historical, but the portion dealing with those stages which preceded that of the Indo-Aryan Vernacular lies outside the frame of the present work, and my account of them will be as brief as is consistent with gaining a clear idea of the whole subject. ${ }^{1}$

48. The earliest documents illustrating the language of the Indo-Aryans that we possess are the hymns of the Rg Vèda. These hymns were composed at widely different times and in widely different localities, some in Arachosia and some in the country near the Jamnā, but, owing to their having undergone a process of editing by those that compiled them into their present arrangement, they now show few easily recognizable traces of dialectic differences. ${ }^{2}$ On the other hand, it is certain that even at that early period "there must have existed a popular language which already differed widely in its phonetic aspect from the literary dialect", 3 and that this folk-language varied so

It is necessary to explain that this chapter was originally drafted in the year 1898. It was then deemed advisable to postpone the publication of the work till the Linguistic Survey of India should be near completion. In the meantime, I utilized the draft for the preparation of pp. 51-63 of The Languages of India, published in 1893 . The chapter has now been rewritten, but. so much of the original as had not become out of date was retained. Hence, much of what follows will also be found in the above work, which; however, goes into the matter in much greater detail.

${ }^{2}$ Cf., however, von Bradke, ZDMG. xl, $673 \mathrm{ff}$.; Wackernagel, Altindische Grammatik, xiii, xix, xxxv.

${ }^{3}$ Macdonell, History of Sanskrit Literature, 24; cf. Wackernagel, xvi ff., xxv. 
greatly from place to place that Indo-Aryan speakers of one locality were unintelligible to Indo-Aryan speakers of another. ${ }^{1}$ In the process of editing the hymns much of the original dialectic variations have disappeared, and there has even been, as has always been the tendency in literary India, a disposition to use exceptional forms as bases for generalizations ${ }^{2}$; but, nevertheless, the hymns, even as we possess them, form an invaluable record of the Aryan language of ancient India, especially of that of the Eastern Panjāb and of the Upper Gangetic Dōāb, where they were compiled.

49. It is impossible to trace the origin of these ancient dialects in detail, but one general theory must be stated, which not only has the authority of a distinguished philologist, but is also supported by a leading Indian ethnologist. ${ }^{3}$

50. On purely linguistic grounds, Hoernle ${ }^{4}$ considered that at some former period of its history North India was divided between two great forms of speech which he calls the "Śaurasēnī tongue" (Western) and the "Māgadhì tongue" (Eastern) respectively. He further suggested that at a still earlier period the limits of the Mágadhi tongue included a much wider extent of country. He finds isolated traces of Māgadhi characteristics in the far west. These increase in number as we proceed east, till at last in the east itself they predominate so as to constitute the Māgadhi tongue. These circumstances, he maintains, seem to disclose the fact that at some time in the remote past the Mãgadhi tongue must have reached up to the extreme north-western frontiers, and have been the only language of North India; but that in course of time it gradually

1 Hillebrandt, Vedische Mythologie, i, 89, 114, 136.

2 Cf. von Bradke, $669 \mathrm{ff}$; Wackernagel, xii.

3 See Risley, Report of the Census of India (1901), i, 511, repeated in the Imperial Gazetteer of India (1907), i, $302 \mathrm{ff}$. According to him, the earlier Aryan invasion suggested by Hoernle, and mentioned below, was one of a tribe or tribes who brought their women with them. The later invaders represent the IndoAryan population of the Midland, which presents the ethnological type that might be expected to result from the incursion of a fair long-headed race that entered India by a route which prevented women from accompanying them, into a land inhabited by dark-skinned Dravidians, whose women they took for themselves. It is thus seen that Risley postulates two sets of invaders, one bringing their women and settling at first in the Central and Western Panjāb, and the other coming without their women and settling at first in the Midland. It is evidently immaterial to his argument which was the first and which the second, but he assumes that the first was that with women.

- Gaudian Grammar, xxx ff. 
receded more and more to the south and east before the advancing tide of the Śaurasenni tongue, leaving, however, here and there in the deserted territories traces of its former presence. With this Mägadhĩ tongue Hoernle associated Paṣ̆tō and Kāfirī, and concludes, "It would'appear from this that Māgadhì Prakrit and the Paṣ̆to and Kăfiri were once in close connexion, perhaps one language, and that at some time in the remote past they became separated by the Saurasēni Prakrit tongue, like a wedge cleaving them asunder and gradually pushing the Māgadhi further and further away towards the East."

51. I have quoted at length this eminent scholar's theory, and now proceed to state my own opinion which is founded upon it. In the first place, it must be remarked that, since Hoernle wrote, it has been proved that Paṣ̆tō is an Eranian language, and hence can hardly have been closely connected with the Indo-Aryan Māgadhì tongue. As regards Hoernle's Kāfiri, by which he means Bašgalï, one of the Modern Pisanca languages, the case is somewhat different. In some respects Modern Pišáca differs widely from the North-Western Indo-Aryan Vernaculars, i.e. Lahndā and Sindhi, while in other respects it closely agrees with them. Reference has already been made to this point (ante, $\S \S 10,24$, 25), and I have stated my opinion that the points of agreement are due to the intermingling of the ancient speakers of the old form of Paisanci Prakrit with the Indo-Aryans of the north-west-in other words, that they are due to very ancient borrowing by the latter. Otherwise I am unable to account for the existence of Eranianisms in Modern Piśāca that are wanting in Lahndā and Sindhī. On the other hand, it is evident that Kāšmīìi, a Modern Piśāca language, either has borrowed freely from the NorthWestern Indo-Aryan Vernaculars, or else is a connecting link between the two groups. Possibly, when we know more about Modern Piśāca, it may be shown that I am wrong, and that Hoernle's instinct was justified in suggesting that the old Prakrit of the north-west, i.e. Hoernle's old Măgadhi tongue, and the ancestor of Modern Piśāca were once in close connexion or perhaps one common language. ${ }^{1}$ My mind is entirely open on the point.

1 Three interesting points are on Hoernle's side. One of them is the optional change of $r$ to $l$ in Cūlikāpaišāeika. The same change was obligatory in Mãgadhī Prakrit; cf. Mlahäbhăsya (Kielhorn, i, 2, 1.8), hè 'layō for hē arayah, in the speech of the Asuras, which is often said to be Mangadhi l'rakrit, but can be better explained as Cũlikāpaiśácika Prakrit. The second is the change of $s m$ to $\&$ 
52. I nevertheless believe that the North-Western Indo-Aryan Vernaculars, whether of common origin with Modern Piśāca or not, are much more closely related to Hoernle's Mägadhī tongue than even he supposed. ${ }^{1}$ In other respects also his contention seems to me to be entirely justified, and, so far back as we can trace the linguistic history of Northern India, we find a "Māgadhi Prakrit tongue" occupying the north-west, south, and east, with a wedge of Saurasēni in the Midland, which it embraces on three sides. Now, the Aryan invasion of India was a process extending over several centuries. The Vêda itself shows this. There are, for instance, hymns that treat of Divōdāsa of Arachosia as a contemporary, and there are others that tell of his descendant, Sudās, who dwelt in the Panjāb, and in whose days the martial exploits of his ancestor had already become legendary." 'This invasion may have been gradual, or, as Risley (op. cit.) suggests, there may have been two different Aryan invasions at widely separated periods. For our present purposes, it is immaterial which was the fact. If it was gradual, then the first comers differed from the latest as widely as if there had been separate invasions instead of a continuous one. Sudās's hymn-writers tell us how he conquered the Pūrus, another Aryan tribe far. to the east, on the Jamnā, whom they called mrdhravāc, of barbarous speech. ${ }^{3}$ Again, we have a valuable reference to the struggle between the Aryans of the Western and those of the Eastern Panjāb, in the contest between the Western Brāhmana Vasiṣtha and the Eastern Kṣatriya Viśvāmitra. ${ }^{4}$ Similarly, the war of the Mahäbhārata between the Kurus and the Pâñālas gives us hints as to the state of affairs at a later stage of history. Since Lassen's time it has been recognized that the latter were older settlers than the former, and it is an interesting fact that, broadly speaking, their allies belonged to the South Midland and Pañcala, or East Midland, while the Kurus had allies from the north-west, the south, and the east.

(K.̌. $a s^{i}$, "we," etc.). See Hoernle, Gd. Grammar, 280, n. 1. The third is the frequent use of $\tilde{n}$ both in Paiśāei Prakrit and in Măgadhī Prakrit (Hêmacindra, iv, 305, etc. ; cf. Hoernle, Gd. Grammar, 11).

1 This point is discussed in detail in an Appendix to this chapter.

${ }^{2}$ Hillebrandt, 104 ff., 109.

3 Tb. 114.

4 Hillebrandt, 110, also maintains that there was a second invasion of Aryans from the west. It is worth noting that Viśvamitra called Vasiștha a Yàtudhãna, or Rākṣasa, a form of abuse that the latter strongly resented (Rv. vii, 104, 15 ). 
This would illustrate a later stage of the struggle. The Pāñālas of the East Midland would be the representatives of the "Māgadhi Prakrit tongue", opposed to the Kurus coming of the West Midland and Eastern Panjāb. The fact that the Kurus are described as having allies in the extreme east can hardly affect the question. We can accept the original authors of the old Bhārata lay (circ. 400 B.c.) as authorities for the centre and west of Northern India, but references to settled kingdoms in the Far East must be ascribed to later writers. Political considerations affected the conduct of the nations immediately to the east of Pañcāla, viz. Eastern and Western Kōsala, Vatsa, Kà̉s̄is, Vidēha, and Eastern and Western Magadha. ${ }^{1}$ Some of these sided with one party and the others with the other. Making these subtractions, we find that the war was one between the Brahmanical Kurus of the West Midland and the AntiBrahmanical Pāñcālas to their east. ${ }^{2}$

53. It is to be noted that the Rāma legend belonged to Eastern India, while the Mahābhärata (originally with Kurus, not Pāñcalas, for its heroes) belonged to the Midland. Nevertheless, the connexion of the east with the north-west was close. The progenitors of Rāma, the Ikșwākuides, whose home was in Kōsala, east of the Midland, belonged originally to the extreme Northwest (Ram. II, lxviii, 17), hailing from the Ikșumati, close to the Satadru. Moreover, it was from this country, not from the Midland, that Daśaratha took his wife Kaikēyi. ${ }^{3}$ Lassen points out that in the Satapatha Brahmana the Kurus were connected with the Bahlikas of the land beyond North-Western India, and that their allies, the Sauviras, 'Madras, and Kaikeyas, though Aryans, are called Mlëcchas. He maintains that the Pāñālas were earlier immigrants, and even suggests that they had been so long in India that their colour had changed from fair to dark. ${ }^{4}$

54. It was in the West Midland that the Vedic hymns were collected and edited, and it is hence reasonable to assume that they represent in the main the language of that part of Northern India. Here, also, in later times was the centre of Brahmanical

1 The kingdom of Magadha was, as a whole, hostile to the Midland; see Jacobi, Das Rämāyana, 104.

2 Pargiter, JRAS., 1908, 334 ff., and map; Grierson, ib., 602 ff.

: Jacobi, op. cit., 69.

+ LIA $^{2}$. i, 720, 742, 743, 791 . 
culture, here arose classical Sanskrit, ${ }^{1}$ and here a non-classical speech developed in the mouths of the people from the ancient vernacular of which we find the literary form in the Vedic hymns, and which was the ordinary language of mutual intercourse. ${ }^{2}$ In the literary circles of the Brāhmanas, the language of later Vedic literature, i.e. that of the sütra period, ${ }^{3}$ continued as the polite language and the language of literature, and was fixed by the labours of grammarians culminating in Pannini (circ. 300 B.C.). This language, so fixed, was known by the name of "Sanskrit" (Sanzslerta, purified ${ }^{4}$ ), while the language of the common people, the lōka of Patañjali, ${ }^{5}$ was called "Prakrit" (Prākrta, natural, unsophisticated). In Patañjali's time correct Sanskrit was spoken in its puritied form only by poor learned Brāhmaṇas who had been specially taught grammar. ${ }^{6}$ Other Brāhmaṇas spoke incorrect Sanskrit, ${ }^{7}$ while the uneducated people spoke a form of Prakrit. As the language of literature, Sanskrit held a monopoly in the west; but in the east of Northern India, where the Brahmanical influence was not so strong, and which was the centre of antibrahmanical reform, Prakrit was also used for this purpose. ${ }^{8}$

55. From this definition of the term "Prakrit", it follows that the vernacular dialects, the literary form of which is preserved in the Vedic hymns, were essentially Prakrit, and as such they may be called the Primary Prakrits of India. The vernaculars that developed from them and which continued developing in various phases, alongside of the Sanskrit whose growth had been arrested or retarded by the grammarians of the Brahmanical schools, may be called the Secondary Prakrits, while the final development-the modern vernaculars of the present day-may be called the Tertiary Prakrits. ${ }^{9}$ It is with these Tertiary Prakrits that we are immediately concerned.

1 Wackernagel, xxxiv.

2 The earliest examples of this are to be found in the inscriptions of Asolia (circ. 250 B.c.), and in the Mahābhāṣya (circ. 150 B.c.), R. G. Bhandarkar, Witson Lectures, 280.

${ }^{3}$ Wackernagel, xxxii, xxxiii ; Liebich, Pänini, $47 \mathrm{ff}$.

4 See Thomas, JRAS., 1904, 471, 748.

5 e.g. Kielhorn, i, 259, 1. 14.

6 JRAS., 1904, 480.

7 Jacobi, Ramãyana, 114 ; Muir, Sanskrit Texts, $\mathrm{ii}^{2}, 158$; Wackernagel, xxxviii, n. 6 .

${ }^{8}$ Cf. Sylvain Lévi, Bull. Soc. Ling., 8, pp. viii, $\mathrm{x}$, xvii, quoted in Wackernagel, xxxix, 1 .

9 The Primary Prakrits plus their literary form as conserved in the Veda correspond to Wackernagel's "Altindisch", and the Secondary Prakrits plus their literary form to his "Mittelindisch". 
56. It stands to reason that no distinct border-line can be drawn between the Primary Prakrit, or Prakrits, and the secondary Prakrits, ${ }^{1}$ or between the Secondary Prakrits and the 'Tertiary. If we exclude sporadic traces in the Véda, the Secondary Prakrits first appear to us in literature in the inscriptions of Asōka (third century B.C.), and here we find them in their first phase, but in a state of full development. We'know, on the other hand, that the transition from the Secondary to the Tertiary Prakrits was so gradual that, at or about the approximate border-line, it is impossible to state to which stage the language belongs. At the same time there is no difficulty in recognizing the main characteristics of each stage. In the primary stage the language is synthetic, and has no objection to harsh combinations of consonants. In the secondary stage, the language is still synthetic, but diphthongs and harsh combinations of consonants are eschewed-so much so that, in its latest artificial literary phrase-the Māhārāṣtrī Prakrit-it arrives at a condition of almost absolute fluidity, becoming a mere emasculated collection of vowels hanging for support on to an occasional consonant more lucky or more hardy than its brethren. This weakness brought its own nemesis, and in the 'Tertiary stage we find the hiatus between contiguous vowels abolished by the creation of new diphthongs, declensional and conjugational terminations, consisting merely of vowels, worn away, and a new kird of language taking shape, no longer synthetic, but analytic, and again reverting to combinations of consonants under new forms, which had existed three thousand years before, but which two thousand years of attrition had worn away. Nay, more, in the Outer Indo-Aryan Vernaculars we see the analytic form of language again disappearing, and in the process of being replaced by a new synthetic form comparable, in its principles, with that of Primary Prakrit. ${ }^{2}$

${ }^{1}$ It is quite certain that even in the Vedic period the popular speech of at least some classes of the people already contained many words in the same stage of development as Pāli, i.e. as the earliest phase of Secondury Prakrit. Cf. Wackernagel, xviii, xxv.

2 It is always the Midland which has been behindhand in the race of develop. ment. Śaurasēni Prakrit is less developed than Māhārāsțī Prakrit, just as the Modern language of the Midland is less developed than any of the Outer languages, including Maräthi. Is this because the inhabitants of the Midland represent the latest Aryan immigrants (see above), or is it due to the influence of literary Sanskrit-itself a Midland language? Opportunity may here be taken to warn against one common error. It has often been stated that because (e.g.) Śaurasēni 
57. We know that the Primary Prakrit had dialects, and it therefore follows that there must also have been dialects of the Secondary Prakrits even in their earliest phase, but we do not obtain any certain information on the point till we come to the Asōka inscriptions already mentioned. In them we find that the then existing Aryan vernaculars did include at least three main dialects, an eastern, a western, and a north-western. ${ }^{1}$ As to whether there was at that time a southern dialect we do not know. ${ }^{2}$

58. The particular phase which the Secondary Prakrits had reached at this time was that of which Pāli is the literary representative. As vernaculars they continued their course of development, and, in various dialects entered the phase of

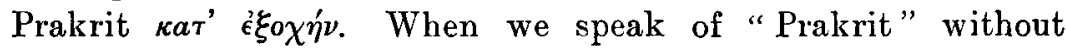
qualification, we mean this latter phase of the secondary Prakrits, when they had developed beyond the phase of Pāli, and before they had reached the analytic stage of the Indo-Aryan Vernaculars.

59. These Prakrits became, in later times and under the influence of religious and political causes, the subject of literary study. Poems and religious works were written in them, and they were freely used in the drama. Grammars of the various dialects were written by contemporaries or by men who lived a comparatively short time after they had become dead languages. Here again we see the same Indian proclivity to turning tendencies into, or even to use exceptional occurrences as the basis

Prakrit is less developed than Māhārāșțrì, it is therefore earlier in point of date. Such an argument is fallacious. It is a well-known fact that different languages of a common origin do not all develop at the same rate of progress. To take an example from the Romance languages, Italian is much less developed than French. To use Indian terms we might almost say that Italian is in the Pāli stage, while French is in the Prakrit stage. Nevertheless, they are contemporary.

${ }^{1}$ Cf. as the latest authority, Michelson, AJP. xxx (1909), 284, 416, xxxi (1910), 55 ; JAOS. $x \times x$ (1909), 77, xxxi (1911), 293 ; also Grierson, JRAS., 1904, 725. The eastern dialect in the days of Asōka was the official imperial language, and was understood even where it was not spoken as a vernacular (JAOS. xxx, 77).

2 The Brahmagiri (Siddapura) Edict is written in a mixture of eastern and western forms (Bühler, EI. iii, 135). But this, being in a Dravidian country, is not decisive. Cf., however, the close connexion between Mahārāṣțrī and Ardha-Māgadhī Prakrit. Wackernagel (xxi) considers that there were probably in Vedic times an eastern and a western dialect. The eastern, which was the language of the earlier Aryan immigrants, was then spoken on the banks of the Ganges. The literary language of the Vêda would, in the main, correspond to the western dialect. We cannot trace in the Veda any marks of a dialect of the extreme north-west, but we can deduce nothing from their absence. 
of, general rules. ${ }^{1}$ The Prakrit spoken was bound by only one universal rule-the convenience of the speakers-but the grammars and the literature based upon them altered this speech in important particulars. The writers omitted what they considered to be vulgar, reduced wild luxuriance to classical uniformity, and thus created artificial products suited for the artificial literature which has ever been popular in India. For instance, the laws of the development of the language created a tendency to drop medial consonants. The grammarians made this a universal rule for certain consonants, so that, e.g., ${ }^{2}$ mata-, mada-, maya-, mrga-, and mrta-, all became maa-, and kāka-, kāca-, and $k \bar{a} y a-$, all became $k \bar{a} a-$. Such a language must have failed to fulfil the main purpose of any language-that of conveying intelligible thought-and could never have existed as a general means of communication. That there was a tendency to drop such medial consonants is certain, but various automatic devices came at the same time into being which preserved intelligibility at the cost of that consistency on which the grammarians set so great store. One of these was to arrest the phonetic development of a word at that particular point at which its further development would have led to its confusion with another word. As an example take the word $k \vec{a} k a$ - given above. The ordinary course of development would have been $k \bar{a} k a->k \bar{a} g a->k \bar{a} a-$. We have proofs from the Indo-Aryan Vernaculars that development in the mouths of most Indians stopped at kaga-. The genius of the vernacular felt that $k \bar{a} a$ - would lead to confusion, and resisted the tendency towards phonetic indolence that urged it to drop the $g$. It has accordingly retained $k \bar{a} g a$ - unchanged down to the modern Hindi, where it still appears under the form of $k \vec{a} g$, in spite of the efforts of the long series of Prakrit grammarians. Other Indians, it is true, gave way to the tendency, but saved the cause of intelligibility by the use of pleonastic suffixes, of which a great variety were to hand. So, in the ease of $k \bar{a} a-(<$ kaga-), they distinguished the meaning of "crow" by appending the suffix uaa( $<$ ukaka-), and the word became kauaa -, which is the parent of the Hindi kauwā. As for kāca-, it never lost its original form, for

1 We must, however, credit the grammarians with expressly warning us that their rules are not universal ; cf. Hc. i, 2 ; see also R. G. Bhandarkar, op. cit., $7 \tau$, n., "all these rules are general, not universal."

2 Pischel, Prakrit Grammar, $\$ 12$. 
the order of development would have been $k \bar{a} c a->k \bar{a} j a->k \bar{a} a-$. But $k \vec{a} j a-$ was already appropriated by kajja- or $k a \bar{j} j a-<k \vec{a} r y \alpha-$, and hence the development of $k \vec{a} c a$-was stopped from the very first, and we have still $k \bar{a} c$ in modern Hindi, usually but unnecessarily described as a tatsama (see below). Kāya- alone really became $k \bar{a} a$ - in the latest stage of the Secondary Prakrits. ${ }^{1}$ In short, too much stress cannot be laid on a fact which seems to have been ignored by many writers, that no language in the world has ever developed homogeneously on regular lines, as if it were a mathematical problem. At no stage is it possible to draw a line at which it will be found that all the words in use have arrived at the same stage of development. The most that we can say is that the majority have arrived at that stage, while, on the other hand, the development of many words has been retarded, or even hastened, by various causes such as desire for intelligibility, religious tradition, or political prejudice. ${ }^{2}$

60. Before dismissing this part of the subject, it is necessary to warn the reader that he must not expect to find the Seqondary Prakrits or the Indo-Aryan Vernaculars, to be each shut up in a watertight compartment. There has always been much reciprocal borrowing among them, so that in one Prakrit or IndoAryan Vernacular we often find words belonging to another. This was mainly due to the fact that there appears always to have been in India some particular dialect which was used as a $\kappa o \iota \nu \eta^{\prime}$-at one period of history one, at another, another. This depended largely on political and literary factors. In early times Sanskrit, so far as any Aryan language was spoken, was the universal language of polite society all over Northern India, and thus brought the influence of the West Midland to bear on

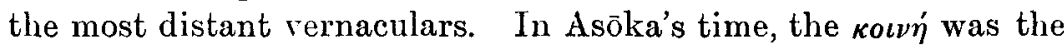
eastern language of Magadha, as we know from numerous examples of Mägadhi in the most distant inscriptions. ${ }^{3}$ On the

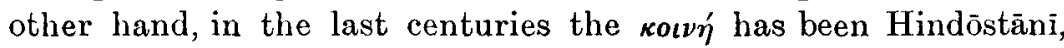
essentially a Midland language, and even in tongues so different from it as Bengali many Hindōstāni words have been incorporated and admitted to full citizenship in more or less distorted forms.

${ }^{1}$ Cf. Pischel, \$364. Regarding the changes which Prakrit has undergone in becoming literary, see ib., $\$ 9$, at end.

${ }^{2}$ For the last, compare the change of pronunciation of Mãgadhī Prakrit $s$ to 8 in Bihāri, although s is invariably written.

${ }^{3}$ See, for instance, Michelson, AJP. xxx, 285. 
Similarly Bihārì, which has always been historically connected with Awadh, the home of Eastern Hindi, has abandoned the Māgadhi Prakrit pronunciation of $s$ as $s$, although it always preserves the $s$ in writing. Again, the literary Prakrits, as time went on, lost their characters as local forms of speech, and each became the universal language of a special kind of literature. Māhārāșțī Prakrit monopolized the Prakrit Iyries and kāuya, and Śaurasēni Prakrit and Māgadhi Prakrit became the dialects used, not by natives of any country, but by particular classes of characters in the drama. "It is clear that a language such as Māhārāșțri Prakrit, which was largely used by lyrical poets from all parts of India, would in course of time adopt words and perhaps also inflexional forms from other vernaculars than that which was its original base. On the other hand, it would naturally influence the spoken vernaculars. The language of lyrical poetry is, of course, more apt to exercise such influence than that of any other branch of literature. Every Prakrit, and especially Māhārāșți Prakrit, should therefore be expected to be more or less of a mixed character, and this is undeniably the case." 1

61. Owing to their deformation at the hands of grammarians and their followers, a veil which it is not always easy to lift, is drawn between the literary secondary Prakrits in their "Prakrit" stage and the true vernaculars of their time. We are able, however, to distinguish, as in the Asồka inscriptions, an eastern and a western Prakrit, each possessing distinctly marked characteristics. $^{2}$ The principal form of the western was Saurasēni, the language of the Midland and of the eastern, Māgadhi, the language of Magadha, the present South Bihār. Between these two there was a kind of neutral ground, the language of which was Ardha-Māgadhì, or half-Māgadhì, partaking of the nature of both languages. Closely connected with the last-named, but leaning rather to the eastern than to the western, was Māhārāștrīi, or language of the present Varhāḍa (Berar) and the country adjoining. Moreover, in the extreme north-west there was an unnamed speech, ${ }^{3}$ which was a

1 Konow, IA. xxxii (1903), 181.

2 For this division of the Prakrits, see Konow, Māhārästrī and Marāthi, IA, xxxii (1903), $181 \mathrm{ff}$, with which I am in entire accord.

${ }^{3}$ Mārkandeya, xvi and comm. to xviii, perhaps calls it Tăkki or perhaps Pāścātya. Cf. Rāmatarkavagíśa in Lassen, ILP., App. p. Ј̆, and Hoernle, Gḍ. Gr., 15 , n. 1 . 
development from the particular primary Prakrit spoken on the banks of the Indus, and whose existence is vouched for by the reference to it in the next phase of the secondary Prakrits to be immediately described.

62. The phase referred to at the end of the preceding paragraph is that known as "Literary Apabhramsa". The word apabhramśa means "corrupted" or "decayed". Applied to a language it means, from the point of view of the philologist, "developed." The secondary Prakrits became fixed and stereotyped for literary purposes by the grammarians, but the vernaculars on which they were founded continued to develop, and, as compared with the literary Prakrits, they were looked upon as corrupt. By the time the literary Prakrits had become dead languages, the Apabhramśas also received literary cultivation, and in their turn fell into the hands of the grammarians. The earliest of these to deal with them of whom we have literary remains was Hêmacandra (twelfth century A.D.), and in his time they were dead languages. ${ }^{1}$ The writers in literary Apabhramśa treated it as based upon the literary Prakrit. To them it was prākrtō 'pabhramiśah (Pischel, Pr. Gr., p. 30), i.e. they wrote in a Prakrit modified by the peculiarities of the contemporary vernacular, not in the true vernacular-the real Apabhramśaitself. Just, therefore, as is the case with the literary Prakrits, we cannot expect the literary Apabhramśas to give a true picture of the real vernacular. The works in Apabhramsía are of varying date and differ among themselves and from Hemacandra as to the amount to which the literary Prakrit has been altered to approach the vernacular. But, nevertheless, when used with caution they impart valuable information as to what that vernacular was.

63. Turning now to the real Apabhramsas - the actual Aryan vernaculars of the people-they were spoken during the later centuries of the first millennium after Christ. ${ }^{2}$ To each Prakrit there was a corresponding Apabhramśa. Thus there was a Śaurasēna Apabhrạ̣śa corresponding to Śaurasēni Prakrit,

1 See the dates fixed in $\S 66$, post. Apabhramśas could hardly have been a living language in Hēmacandra's time, for his grammar does not deal with one A pabhramsia, but with several dialects which he mixes up together. His very rules are frequently contradicted by his own examples. He would not have done this had he been dealing with a living language known to him. In this respect, his grammar is a compilation put together from many widely differing and mutually contradictory sources (Pischel, Pr. Gr., \& 28).

2 R. G. Bhandarkar, Wilson Lectures, 302. 
a Māgadha Apabhramía corresponding to Māgadhī Prakrit, a Māhārāștra Apabhraṃśa corresponding to Māhārāṣṭī Prakrit, and so on (Pischel, Pr. Gr., §5). To these can be referred nearly all the Indo-Aryan Vernaculars. To Śaurasēna Apabhramía are to be referred Hindī, Rājasthānī, and Gujarātì, the last-named being closely connected with the Nāgara form of Śaurasēna (see below). To Māgadha Apabhramiśa belong Bihārí, Bengali, Assamese, and Oriyā; to Ardha-Māgadha Apabhraṃśa, Eastern Hindī; and to Māhārāṣtra Apabhraṃśa, Marāṭhi. There remain the north-western group. There does not seem to have been a literary Prakrit for this part of India, but for Sindhi we can fall back on the Vräcada Apabhramśa of the grammarians (see below). For Lahnda no corresponding Apabhramsia is known and we must assume a Kaikēya (cf.the Kēkaya Paisanāi of Mārkaṇdẹya, xix) Apabhraṃ́a, which was closely connected with Vräcada. The Indian grammarians did not divide the literary (as distinct from the read) Apabhramsa in this fashion. They knew of three chief literary dialects, a Nāgara, a Vrācaḍa, and an Upanāgara. The first was the principal dialect, and seems to have been that spoken in the country now inhabited by the Nāgara Brahmanas of Gujarăt, a tribe long celebrated for its learning and which, according to Nagēndranātha Vasu (vide ante, $\S 14$, n. 1), gave its name to the Nāgari alphabet. Hēmacandra was also an inhabitant of Gujarāt, and the Apabhramśa described by him claims (iv, 446) to be based on Śaurasēni Prakrit, although, as already remarked, much of what he teaches really belongs to other forms of the language. We may therefore assume that Nāgara Apabhramśa was either the same as or was closely related to Saurasena Apabhramiśa. Vrācaḍa Apabhraṃśa was the form spoken in Sindh. Its peculiarities are described in Pischel, Pr. Gr., $§ 28 .^{1^{\prime}}$ It is noteworthy that, as in the Modern Pisāca languages, it makes little distinction between cerebrals and dentals. Upanāgara Apabhraṃ́sa was a mixture of Vrācaḍa Apabhraṃśa and Nägara Apabhrạ̣śa, and was therefore probably the language of the modern Western Rājputānā and the South Panjāb.

64. Even the Apabhramśa of the grammarians shows clearly the artificial character of literary Prakrit, and how tendencies have there been generalized into universal rules. Apabhramśa is

1 Cf. also Mārkandēya, Preface, 7, and xvii, xviii, and Grierson, "Vrācaḍa and Sindhī," JRAS., 1902, 47. 
in a phase of development more advanced than that of the spoken languages corresponding to literary Prakrit, yet even the grammarians show that it was in a phase much older than that exhibited by these artificial monuments of false generalization. For instance, Hc. iv, 396 expressly states that Apabhramśa does not usually elide, but only softens, certain surd consonants, although these must be elided by the rules of literary Prakrit. Such a Apabhramśa word as sughẽ for sulkēna could not occur in literary Prakrit. There the word would be sukeña. No ingenuity of etymology could make the $h$ of suhena develop into the $g h$ of sughe. The latter is the older form, and shows that the usual pronunciation of the spoken Prakrit on which the literary Prakrit was founded must have been something like *sughena, with a tendency, at most, for it to be pronounced suheña by some lazy speakers. 'The literary Apabhramśa, therefore, though not wholly trustworthy, gives us important information not only in regard to spoken Apabhramśa, but also in regard to the spoken Prakrit on which literary Prakrit was founded.

65. The spoken, or real, Apabhramśas follow, as has been said above, the divisions of the Prakrits. Unfortunately Hèmacandra, our chief source of information regarding them, deals professedly with but one of them, the Śaurasēna (or Nägara) Apabhramśa. We have little definite information regarding the others, although Marrkan deya tells us something; but for our present purposes it is permissible to assume that each Apabhramśa, in, say, the period between the sixth and tenth centuries after Christ, bore, as regards stage of development, the same relation to its corresponding literary Prakrit that the spoken Apabhramsa on which Hēmacandra based his grammar bore to literary Saurasēni Prakrit. Thus, the Skr. sutah, would be sudō in Saurasēnī Prakrit and sudu in Śaurasēna Apabhrạ̣śa. In Māgadhī Prakrit it would be śude, and we are justified in assuming that the corresponding Māgadhi Apabhramśa word would be *śudi, ${ }^{1}$ or something of the sort. Again, the Sanskrit pattah becomes pattō in Saurasēni Prakrit and paśté in Māgadhi Prakrit (Mk.xii, 7), and we may assume that the Măgadha Apabhramśa would be something like *paśti. That this assumption is not irrational is proved by the modern vernaculars.

1 That this is a justifiable assumption is shown by the fact that Mārkandẹya, a late grammarian of the seventeenth century, admits the termination $i$ as well as $\bar{e}$ even into literary Mảgadhì Prakrit (xii, 26). 
Indo-Aryan Vernaculars of the Midland have the nominative of strong $a$-bases in $\bar{o}<\alpha u$, while in the Bengali of the East in old poetry it ends in $\bar{e}<a i$. The dental $s$ of the Midland is written $s$ in Bihārī and pronounced $s$ in Bengali. ${ }^{1}$ I nyself have heard an ignorant Bihārī villager say pasța instead of the Midland patță.

66. The various Apabhramśa dialects represent the concluding phase of the Secondary Prakrits, and from them are descended the Indo-Aryan Vernaculars, or Tertiary Prakrits. It is possible to fix the date at which these took their present form with some approach to accuracy. It is first necessary to trace the various meanings of the word $b h \bar{a} s \bar{a}$. In Pạnini's grammar it was used for the ordinary spoken Sanskrit of the time, i.e. for Classical, as distinguished from Vedic, Sanskrit. Patañjali extends it to include the more or less correct Sanskrit used in conversation concurrently with the Secondary Prakrits of his day. ${ }^{2}$ As R. G. Bhandarkar (287) points out, the root from which the word is derived means "to speak", and therefore the original meaning of the word as a proper noun was "the speech" or "the spoken language". We see this meaning of the word in the Śriharșacarita of Bāna (sixth century A.D.), in which, ${ }^{3}$ in a list of Bäna's companions, is

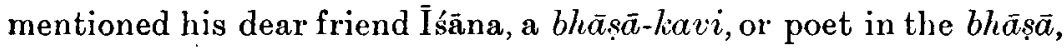
who is differentiated from Väyuvikāra, a Prakrit poet. Here evident]y $b h \vec{a} s \bar{a}$ means the common spoken language of the sixth century, as opposed to the artificial literary Prakrit. In other words İsána wrote in Apabhramśa. In this connexion we may point out that Räjaséekhara (tenth century A.D.) mentions (Bālabhārata, i, 11) four literary languages, Sanskrit, Prakrit, Apabhrạ̣sá, and Bhūtavacana (i.e. Paiśāci Prakrit), as used in his time. Still later (twelfth century A.D.) Kalhana describes Harșadéva of Kaśmīr (eleventh century) as aśêsadéśabläạäjña, or master of countless forms of local speech, and as a good poet sarvablāasa $s u$, i.e. in all languages. Kalhana's very name is either an Apabhramśa or a Tertiary Prakrit form, ${ }^{5}$ and here we may safely conclude that by the déśabhäşās are meant the local tertiary dialects or languages spoken over Northern India, including

: See $\$ 29$, n. 2, ante.

2 R. G. Bhandarkar, 27, 286 ; Wk. xlii.

3 Bomb. ed., p. 47, 11. 6, 7.

- Rājataraingini, vii, 610.

Stein, tr. Räjatarainginī, i, 13, and footnotes. 
Kāšmīī itself. ${ }^{1}$ In a prosody entitled Pir̉galârthapradīpa, ${ }^{2}$ composed in A.D. 1601, the examples of metre consist of verses selected from various older works, and several of these are in praise of princes who were contemporary with the respective writers. The dates of these princes are known, and the verses are in various languages. Bhandarkar points out that some are in Māhārāșții Prakrit, which was evidently at the time that they were written as classical as Sanskrit itself. Others were written in Apabhramśa, and one of these was in honour of a prince named Karna of Cẽdi, who reigned in the first half of the eleventh century. Finally, others are in Tertiary Prakrit, and are in honour of Hammira, who reigned in the thirteenth century. The poet Cand, who is said to be the author of the Hindi Prithīrāj Rāsau, died at the end of the twelfth century. From these data we gather that the Indo-Aryan Vernaculars were employed for literary purposes by at least the beginning of the thirteenth century A.D., and that Apabhramśa was used for similar purposes as late as the eleventh. Allowing the time necessary for any language to gain such favour as to be deemed worthy of being employed for literature, we may. safely consider that the Indo-Aryan Vernaculars had developed from the secondary Prakrits by the year A.D. 1000, ${ }^{3}$ the year in which Mahmūd of $\Gamma$ azni (Ghazni) made the first of his fifteen invasions of India.

67. Concurrent with this long development of the Tertiary Prakrits, and down to the present time, there has existed classical Sanskrit, with all the prestige that religion and learning could give it. It, too, underwent changes in the course of time, but on the whole has remained faithful to the rules laid down by Pānini and his successors. It gradually changed from being a polite language to becoming a school language, occupying much the same position as that taken by Latin in the Middle Ages or by Hebrew amongst the Jews. ${ }^{5}$ Even in Vedic Sanskrit we find examples of words borrowed from the spoken Primäy

1 Kăšmīin was certainly in existence in Kalhana's time, and possibly so far back as the tenth century ; see Stein's tr., RT. v, 397-8n (I, p. 228).

2 Described by R. G. Bhandarkar in Report on the Search for Sanskrit MSS. in the Bombay Presidency for 1887-91 (Bombay, 1897).

${ }^{3}$ On this point ef. R. G. Bhandarkar, 302. He puts the commencement of Apabhramsía at the sixth or seventh century A.D.

- See R. G. Bhandarkar, 21, for the change from the verbal to the nominal style of Sanskrit; cf. Wackernagel, xliv. For dialectic variations, ib., li.

5 Wackernagel, xlii. 
Prakrit, and so, in later times, there are numerous instances of borrowing from the Secondary Prakrits. ${ }^{1}$ On the other hand, the Secondary and Tertiary Prakrits have freely borrowed words from Sanskrit, although the Secondary Prakrit grammarians hardly mention the fact. ${ }^{2}$ We have, however, the express admission of Hèmacandra (iv, 448), and we must also conclude from analogy, that, as at the present day, the more highly educated Prakrit-speaking population freely interlarded their conversation with Sanskrit words. These words, once borrowed, suffered a fate similar to that of the ancient Primary Prakrit words that came down to the Secondary Prakrits by direct descent. They became distorted in the mouths of the speakers, and finally became Prakrit in form, though not by right of origin. ${ }^{3}$

68. Such borrowed words as retained their Sanskrit form were called Tatsama (Ts.)," or "the same as 'that' (i.e. Sanskrit)", while the original Prakrit words, which had come by direct descent from Primary Prakrit, were called Tadbhava ('Tbh.), or "having 'that' (i.e. Sanskrit, or, more correctly, the Primary Prakrit from one of the dialects of which Classical Sanskrit was descended) for its origin". Under the latter name the grammarians also included those Tatsamas which had been distorted in the mouths of the Prakrit-speaking population into apparently Prakrit forms. These I prefer to call Semi-Tatsama (s'Ts.). It is evident that, in the course of events, the tendency must have been for all Tatsamas to become semi-Tatsamas, and for the latter ultimately to become so degraded as to be indistinguishable from Tadbhavas. ${ }^{5}$ Another class of vocables was the so-called Désya (Dś.) words of the Indian grammarians. It included all words that they were unable to refer to Sanskrit as

1 Wackernagel, lii.

2 Some later Prakrit writers, e.g. Rājaśékhara, borrowed Sanskrit words very freely ; cf. index to Konow's edition of the Karpūramañjari.

3 It stands to reason that the modern distortion of a Sanskrit word may often have a result different from that of the gradual development of a Primary Prakrit word. This accounts for many of the so-called irregular Prakrit words noted by the grammarians. To quote an example, Hc. ii, 104, gives a number of irregular forms, $\operatorname{sir} \bar{i}$ (for $\operatorname{si} \bar{\imath})$, hiri $(h r \bar{\imath})$, kiri $\bar{a}$ (kriya), which are really distorted Tatsamas, not Secondary Prakrit. The true secondary form of kriyā is ki $\bar{a}$ (104). So also in the following sūtras.

4 Regarding the subject discussed in this paragraph, see Pischel, Pr. Gr., $\$ 8$.

5 For the use of Tss. in Prakrit. ef. R. G. Bhandarkar, 15, and Wackernagel, liv. For the origin of s'Tss, ef. Bhandarkar, 298. On 69 he gives an account of the so-called Gāthā dialect, which is germane to the present subject. 
their origin. Some such words were included in this group simply through the ignorance of the writers who catalogued them, ${ }^{1}$ and modern scholars can refer several of them to Sanskrit like any other tadbhava. A few others are words borrowed from Dravidian or Mundā languages, but the great majority are words derived from dialects of Primary Prakrit that were not the dialect from which Classical Sanskrit was descended. They are thus true tadbhavas, although not in the sense given to that word by Indian grammarians, in whose philosophy the existence of such ancient dialects found no place. These Déśya words were local dialectic forms, and, as might be expected, are found most commonly in literary works whose places of origin were in countries like Gujarāt, far away from the Midland, the natural home of Classical Sanskrit. ${ }^{2}$ For our purposes we may consider them as identical with tadbhavas.

69. We find an exactly similar state of affairs in the vocabularies of the Indo-Aryan Vernaculars. ${ }^{3}$ Omitting foreign words, such as those borrowed from Dravidian or Muṇāa, from Persian, Arabic, or English, their respective vocabularies may each be divided in to three classes, tatsama, semi-tatsama, and tadbhava. The last class consists of words that the Indo-Aryan Vernaculars have received from the Secondary Prakrits, whether in those Prakrits they were tadbhavas descended from the Primary Prakrit, or tatsamas (including semi-tatsamas) borrowed at that stage from Sanskrit. From the Indo-Aryan Vernaculars point of view, their ultimate origin is immaterial, so long as they were inherited from Secondary Prakrit. The tatsamas and semi-tatsamas of the present day are loan-words, borrowed from Sanskrit in modern times by the modern vernaculars themselves, not by their secondary progenitors. To take an example. The Indo-Aryan Vernacular $\bar{a} j \tilde{n} \bar{a}$, a command, is borrowed direct from Classical Sanskrit. Its semi-tatsama form, which we meet in the same Indo-Aryan Vernaculars, is $\bar{a} g y \bar{a}$, and one of its tadbhava forms is the Hindi $\bar{a} n$, derived from the secondary Prakrit $\bar{a} !(\bar{a}$. So also, rājo $\bar{a}$, a king, is a tatsama, but $r \bar{a} y$ or $r \bar{a} o$, a gentleman, is a tadbhava. It is not often that such complete sets of three or two are in use at the

1 Pischel, Pr. Gr., § 9 ; R. G. Bhandarkar, 107, 131.

2. Saurasenī Prakrit, which developed in the Midland, is naturally that Prakrit which is freest from Ds. words ; ef. Pischel, $\$ 22$.

3 For Tss. and sTss. in Indo-Aryan Vernaculars, see Beames, Cp. Gr. ii, 11 ; Hoernle, Gụ. Gr., xxxviii ; Bhandarkar, 131. 
same time. Frequently only a tatsama or a tadbhava occurs by itself. ${ }^{1}$ Sometimes, as in the case of $r \bar{a} j \bar{a}$, we find the tatsama and the tadbhava forms of a word both in use, but each with a different meaning. Thus, the Sanskrit vamśa has the two meanings of "family" and "bamboo", and connected with it we find the Hindi semi-tatsama bans, a family, and the Hindi tadbhava

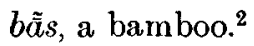

70. It will therefore be understood that the Indo-Aryan Vernaculars tatsamas are really foreign words, and as little belong to the modern languages as do the few Latin words now in use in French or Italian. They are merely an addition to the vocabulary, and in no way affect the grammatical structures of the languages that employ them. They thus, like borrowed foreign words in all languages, rarely change their forms in the processes of grammatical accidence. For instance, the tadbhava Hindi ghōra, a horse, has an oblique case ghōpere, because it is a tadbhava, but ra $\vec{j} j \bar{a}$, a king, does not change in the oblique case, because, and only because, it is a tatsama. Grammatical changes are intimately connected with the history of a language, and the borrowed tatsamas of the Indo-Aryan Vernaculars form no part of its history. Now, in all Indo-Aryan Vernaculars, the verb must

1 Many Primary Prakrit words which have survived unchanged into the IndoAryan Vernacular, and which are hence Tbh., are liable to be confused with Tss. Thus, the Primary Prakrit kara-remained kara-in the Secondary Prakrit, and is still $\operatorname{kar}(a)$ in Hindi. As $\operatorname{kar}(a)$ is also a pure Sanskrit word, it is generally looked upon as a Ts. in Hindi, but it can equally correctly be looked upon as a Tbh. In a book called Thêth Hindī-kā Thāth, by Ayōdhyā Singh Upâdhyãy, from which the author designedly excludes all Ts. words, many honest Thb. words have also been excluded owing to this misapprehension. Nevertheless it, and another work by the same author, Adhkhile $P h \bar{u} l$, are invaluable records of Tadbhava Hindī.

${ }^{2}$ For these specializations see R. G. Bhandarkar, 13. He quotes :-

\section{Tatsama}

vēdanā, any pain.

garbhini, a pregnant female.

täpa-, heat.

hrdaya-, heart.

pinda-, a ball.

cēlaka-, an attendant.

$\checkmark$ gavēs-, search.

r rāja a k king.

kșana-, a moment.

kubja-, a hunchback.

And several others.
TaDbHava

M. vēn, the pains of childbirth.

M. $y \bar{a} b h a n$, only used with respect to the lower animals.

M.G. $t \bar{a} v$, especially the lieat of fever; K.̌. exhaustion.

M. hiyyū, courage.

P.G. pand, the body.

H. cèelä, a disciple; Bg., cèle, a boy.

M. Vyavas, find.

IAV. räy or rāo, any respectable gentleman.

(Prakrit chana); M., san, a festival.

M. khujāa, a dwarf ; kuladia, hunchbacked. 
change its form in the processes of conjugation, while the noun is not necessarily changed in the processes of declension. Hence, nearly all tatsamas are nouns, and hardly any, except in manifest, instances of false analogy, are treated as verbs. If it is necessary to use a tatsama to express a verbal idea, it must be done with the help of another tadbhava verb. For instance, the word darśan, seeing, is a tatsama, and if we wish to use it in the phrase "he sees", we cannot say darśane, but must employ the periphrasis darśan kare, he does seeing. On the other hand, in all the modern vernaculars, nouns need not necessarily be declined synthetically. They can all be also declined analytically. ${ }^{1}$ Hence tatsama nouns, necessarily declined analytically, are common, and in the high literary styles of most of the IndoAryan Vernaculars very common; and, although there are sporadic exceptions to the broad rule, it may be laid down as a general law that Indo-Aryan Vernacular nouns may be either tatsama (including semi-tatsama) or tadbhava, but that IndoAryan Vernacular verbs must be tadbhava.

71. The extent to which tatsamas are used in the Indo-Aryan Vernaculars differs for each: Everywhere in the common speech even of educated people they are few in number, but in some languages, such as Bengali, they flood the literary language to such an extent that it is unintelligible to anyone who has not been specially taught to understand it. In the literary Bengali of the commencement of the nineteenth century, when, under English auspices, there was a general revival of learning, actual counting shows that 88 per cent of the vocabulary of a book called the Purusa-pari $\bar{c} s \bar{a}$ was composed of tatsamas. Of late years an improved literary taste has tended to reduce the proportion in this language, but literary Bengali is still so overloaded with Sanskrit words that it is not understood by the common people. In Hindi the High Hindi of Benares has been showing signs of succumbing to the same fate, but a body of enlightened writers is doing its best to stem this flood of borrowed terms. ${ }^{2}$

1 There are a few exceptions to this. In Kš. and M., for instance, under the influence of analogy, borrowed nouns can be declined synthetically, but the above holds true as a general rule.

2 The late Sudhākara Dvivēdi (Rāmakahāni, p. 7) gives an amusing instance of the difference between literary and colloquial Hindi. A friend wrote to him

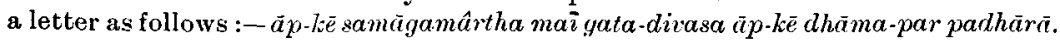

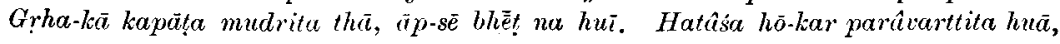


72. Besides Sanskrit other. Indian languages have exercised influence on the Indo-Aryan Vernaculars. The Dravidian and Muṇ̂a languages have had most influence in the Ganges Valley and on Marăthi. The contributions from Dravidian languages have not been unimportant from the earliest times. ${ }^{1}$ In the Tertiary Prakrits such borrowed words are often given a contemptuous meaning, e.g. the Dravidian pillai, a son, becomes the Indo-Aryan Vernacular pillā, a cub. In phonology, if the cerebral letters were not directly borrowed from Dravidian, their development was at least encouraged by Dravidian example. These letters are an essential feature of Dravidian languages. The peculiar development of the letter $l$ in Indo-Aryan languages has also probably been due to Dravidian influence. We may also note the softening of the Indo-Aryan medial surd consonants. $^{2}$ This would have occurred in the course of natural development, but it is also permissible to look upon it as encouraged by Dravidian, in which it is a very prominent feature. Again, we may also mention as probably due to Dravidian influence the double pronunciation of the palatals in Marāthi and in the languages of the north-west, such as Paștō and Kăšmiri, the frequent change of $c$ and $c h$ to $s$, and the eastern change of $s$ to $h^{3}$ In certain languages of the Outer circle, viz. Sindhī and Bengali, and also in Kāšmīrì, in semitatsamas a final short $i$ or $u$ is not dropped as in the Midland, but

i.e. "Yesterday I went to your house to see you. The door of the house was shut, and I did not meet you. I returned home disappointed". Shortly afterwards Sudhākara met the writer of this letter, who, not knowing that it had been

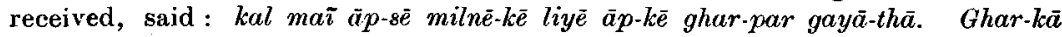

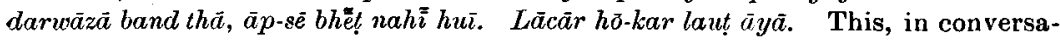
tional Hindi, has exactly the same meaning as the letter in Sanskritized literary style, yet both came from the same man. As Sudhākara observes, the feeling of a pen in the hand of such a person makes him Sanskrit-drunk, and prevents him from using his own mother tongue.

1 Cf. the list of Dravidian words said to be borrowed by Sanskrit on pp. xiv ff. of Kittel's Kannada-English Dictionary. See also Linguistic Survey of India, iv, 278 .

2 Most common and longest preserved in the folk-speech, i.e. Ap.

3 See Konow in Linguistic Survey of India, iv, $279 \mathrm{ff}$, for details. R. G. Bhandarkar (81) attributes the development of Pāli and Prakrit to the mispronunciation of Sanskrit words by alien (i.e. Dravidian) races. I am unable to agree to this. The development, as a whole, exactly followed the same course as that of the Romance languages from the Latin dialects. See Brandreth, "The Gaurian compared with the Romance Languages," JRAS., 1879, 287, and 1880, 335. At the same time I readily admit that Dravidian had some influence on their development. 
is only half pronounced-the mere colour, so to speak, of the vowel being given to the last consonant. Thus, the tatsama murti, an image, becomes the semi-tatsama murat in the Midland Hindi, but is pronounced murati in the Outer Bihāri. This is also a peculiarity of Dravidian.

73. In inflexion, the Dravidian influence is still more apparent. Inflexions have not been borrowed, but those systems of Aryan inflexion which were most consonant with Dravidian practice are the ones that have survived in the struggle for existence. Such are the formation of cases by the use of postpositions added to an oblique form of the noun; the selection of particular Aryan words as postpositions ${ }^{1}$; the adjectival treatment of certain cases, such as the genitive, the ablative, ${ }^{2}$ and the dative $^{3}$; the use of two distinct forms for the accusative case, one of which is always employed when the noun is a rational being; the paucity of forms of the finite verb, and the extension of the use of participles to form tenses; the steady increase in the use of the absolutive-i.e. the conjunctive participle of the Indo-Aryan Vernaculars-which is freely employed in secondary sentences; the increased employment of the periphrastic future in later Sanskrit, which is exactly paralleled by Dravidian use ${ }^{4}$; the employment of such forms as the Sanskrit krtavān (purely Aryan) to form a past tense, which is exactly parallel to the purely Dravidian seydaran. The order of words in the IndoAryan Vernacular, in which the governed word precedes the governing and the verb is placed at the end of the sentence, is also in agreement with Dravidian principles. ${ }^{5}$

74. The influence of Mundā languages on the Indo-Aryan Vernaculars is not so evident. These languages appear to have been superseded on the Gangetic plain of India by Dravidian before the Aryans had occupied that tract. At present they are

${ }^{1}$ e.g. $k r t \bar{e}>k a h \bar{u}>k \bar{o}$ for the accusative-dative, as compared with the Dravidian ku.

2 In Old Gujarātī.

3 In Kāšmîrî.

4 So exact is the parallel that both in Sanskrit and Dravidian the verb substantive is not added to the third person, although it is added to the other two persons.

5 It is to be noted that the Modern Piśáca languages, which apparently did not fall to the same extent under Dravidian influence, differ altogether from the IndoAryan vernaculars in this respect. In them the order of words is nearly the same as in English or as in Modern Persian. For the whule of this subject, see Languages of India, 62, and Konow in Linguistic Survey of India, iv, $279 \mathrm{fr}$. 
confined to the forest country of Central India, although traces of them can be recognized as surviving below the Tibeto-Burman languages of the Central Himâlaya as far west as Kanāwar in the Panjāb. ${ }^{1}$ As Muṇda survivals in the Indo-Aryan Vernaculars we may perhaps note the occasional counting by scores. While the Indo-Äryan Vernacular numeral system is essentially decimal, the word $k \bar{r} r \bar{\imath}$, perhaps itself a Mundā word, is commonly used for "score", and the uneducated people of the Ganges valley use this in the formation of the higher numerals. Thus "fifty-two" would be expressed as "two-score twelve", dio kōr $\bar{\imath}$ bārah. This counting by twenties is a Mundāa peculiarity. The Muṇdās were strongest in the eastern Gangetic plain, and apparently exercised another kind of influence on the eastern dialects of Bihārī (Maithilì and Magahī). In these dialects the conjugation of the verb is much complicated by changes depending on the number and person of the object. These changes are Aryan in their origin, and have parallels in the north-western Indo-Aryan Vernaculars, but the system is that of the Munda verb. ${ }^{2}$

75. Indo-Chinese languages come into contact with the IndoAryan Vernaculars in Assam, in Eastern Bengal, and in the Himâlaya. In the first two a few Tibeto-Burman and Ahom words have been borrowed. In Assam, Tibeto-Burman influence has also been at work in obscuring the distinction between cerebral and dental letters, and in encouraging the retention of pronominal suffixes added to nouns, which has fallen into disuse in other Indo-Aryan Vernaculars except in the north-west. Tibeto-Burman languages employ pronominal prefixes very freely. In the Eastern Pahārī of Nëpāl, Tibeto-Burman languages have affected the grammar more than the vocabulary, and the whole conjugation of the verb bears many traces of their influence. ${ }^{3}$ Another more general fact may possibly be due to Tibeto-Burman example. This is the so-called $b h \bar{a} v \bar{e}$ prayogga of Indo-Aryan Vernacular transitive verbs. In Classical Sanskrit the past participle of an intransitive verb may be used impersonally, as in maya gatam, it was gone by me, i.e. I went. But this idiom

1 LSI. III, i, $273 \mathrm{ff}$.

2 Cf. Konow, LSI. iv, 9.

3 e.g. the use of the agent case for the subject of all tenses of the transitive verb and the creation of a new impersonal honorific conjugation. 
is incorrect with transitive verbs. We cannot say maya māritam for "I struck". But this very idiom, with transitive verbs, is the rule in Tibeto-Burman languages, and is common in all Indo-Aryan Vernaculars except those of the Eastern Group. If this extension, or, possibly, survival of the prayoga in popular speech, although excluded from Classical Sanskrit, is due to Tibeto-Burman influence, it must come from very early times, when the Aryans met, if they ever did meet, 'Tibeto-Burmans on their way into.India.

76. Far more important than the Dravidian, Mundā, or IndoChinese additions to the vocabulary are those which are due to Persian influence. The Persian is not the Eranian language of pre-Musalmān times, although that also has furnished a small quota, ${ }^{1}$ but the Arabicized Persian of the Murul conquerors of India. Through this Persian, Indo-Aryan Vernaculars have also received an important contribution of Arabic and some few Turki words. The influence of the religion of Islām has opened another door for the entry of Arabic, and a few words have been imported on the west coast from Arab traders; but in the main the Arabic element in all the Indo-Aryan Vernaculars came in with Persian, and as a part of that language. The pronunciation of the Persian and Arabic words so imported is still that of Murul times, and not that common in Persia at the present day. Thus in India people say šer, not šs r, for "tiger", and gōst, not gūšt, for "flesh". 2 The extent to which Persian has been assimilated varies much according to locality and to the religion of the speakers. Everywhere there are some few Persian words which have achieved full citizenship and are used by the most ignorant rustic, and we find every variation between this and the Urdu of a highly educated Musalmān writer of Lakhnau (Lucknow), who uses scarcely a single Indo-Aryan word except the verb at the end of the sentence. Under all circumstances it is the vocabulary, and but rarely the syntax, which is affected. The additions to the vocabulary are, as in the case of tatsamas, nearly confined to nouns substantive (see $\S 70$ ). Only in the Urdũ of Musalmāns do we find the Persian order of words in a sentence, and there

1 e.g. the Sanskrit and Prakrit săhi, a king, not derived from the Musalmān

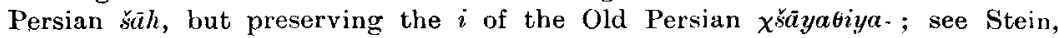
"Zoroastrian Deities on Indo-Scythian Coins," Oriental and Babylonian Record, August, 1887.

" Hence the spelling "Hindōstān", not "Hindūstān", is correct in India. 
has been no other introduction of Persian construction, except that which is actually borrowed as a construction with Persian words. Nor are Arabic words inflected except by purists, but they have to conform to the grammatical system of their host. So strong is the native instinct against the use of foreign constructions, that Hindū writers class a dialect as Urdū, not on the basis of its vocabulary, but on that of the order of words employed. ${ }^{1}$

77. Other languages have also contributed to the Indo-Aryan Vernaculars vocabularies. The principal of these are Portuguese and English. As examples of Portuguese we may quote kamrä (camera), a room; mārtōl (martello), a hammer; and nīlām (leilão), an auction. English words are very numerous. Such are $j a j$, a judge ; istant, an assistant; digri, a decree; inc, an inch; and so on. Many words when borrowed are distorted into some Indian word of somewhat similar sound, and with more or less allied meaning. Thus a railway "trolley" becomes " $t h \bar{e} l$ " -gā $r \bar{\imath}$, or "push "-cart, a "signal" becomes "sikandar", and "signalman", "sikandar-mān", or "the pride of Alexander". The free use of English words has greatly increased of late years among the educated. I have heard an Indian veterinary surgeon say "kutteka saliva bahut antiseptic hai", i.e. "a dog's saliva is very antiseptic", and the 1911 Census Report for the United Provinces

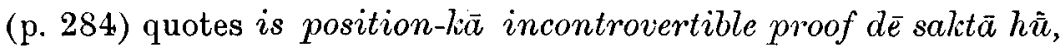
aur mêrā opinion yeh hai ki defence-kā argument water-hold nahz̃ kar sulktā-hai, "I can give incontrovertible proof of this position, and it is my opinion that the argument of the defence cannot hold water." It will be observed that not only all the verbs but also the grammar and word-order of this are purely Indian. Only the nouns are borrowed. The expression "to hold water" has become "to do water-hold", and includes an Indian Tatpurusa compound not in the original. This kind of "pidgin" language is used not only to Englishmen, but also by educated natives when talking amongst themselves.

78. The two main additions to Indo-Aryan Vernaculars vocabulary are, however, tatsamas and Persian (including Arabic) words. The tatsamas owe their origin to educated Hindūs, and the Persian words to educated Musalmanns and to Hindus educated

1 e.g. a well-known Hindi work, written in the last century, was called

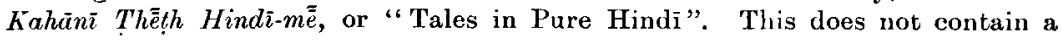
single Persian word, and yet Hindū writers class it as Urdū on account of the order of the words. The anthor was a Musalmān. 
on Musalmān lines (vide ante, $\S \S 6,7$ ). Their use, therefore, follows religion rather than language. We may, however, state that, so far as the literary forms of speech go, those of the east and south generally prefer tatsamas, while those of the West Midland and of the north-west prefer Persian (including Arabic). This is well shown by the following table, which is based on Beames, Cp. Gr., i, 40 :-

Lahndā. Panjābī. Hindì. Eastern Hindī. High Hindī. Bihārī. Bengali. Sindhī. Gujarātī. - Marāthī. Oriyā.

Here the north-western Indo-Aryan Vernaculars, Lahndā and Sindhī, spoken mainly by Musalmäns, are strongly infected by Persian and Arabic. In the extreme east, where the literary classes are mainly Hindū, tatsamas largely predominate in Bengali and Orjyā. The other languages occupy intermediate positions: as shown, Hindi has to occupy two places; for the literary Hindi of $\bar{A}$ grā, in the west, has much fewer tatsamas, and uses Persian words more freely than the High Hindi of Benares in the east. Urdū, which is extremely Persianized, has to be left out of consideration, as it is the literary lingua franca of the whole of Northern India. Assamese, owing to its isolated position, has fewer tatsamas than Bengali, and occupies in this respect a quite independent position. It is therefore omitted from the table.

79. There remains the history of the Modern Piśáca languages. Regarding these nothing certainly historical can be established, except that in the time of Asōka, a language possessing phonetic characteristics similar to those of Modern Piśáca was spoken in the same locality. ${ }^{1}$ 'The Shāhbāzgarhī and Mansehrā inscriptions are decisive on this point. We have no certain data as to where the Paisáci Prakrit in the form described by Hēmacandra was spoken, but if. as is possible, it was the language of the Pisancas of Central India (vide ante, $\S 35$ ), it cannot be expected to throw much direct light on the Paiśāci Prakrit of the north-west, although it throws much more than is admitted by some scholars. $^{2}$ In some respects Modern Piśáca agrees with the

1 See Grierson, "Linguistic Relationship of the Shăhbāzgaṛi Inscription": JRAS., 1904, 726.

2 The Paiśáci Prakrit of Vararuci differs from Hēmacandra's Standard Paiśāci Prakrit in important particulars, and has, like Hēmacandra's Cūlikāpaiśācika, a closer relationship with the north-west; cf. Grierson, The Pisiaca Languages of North-Western India, 6. 
Eranian $\Gamma$ alcāh languages of the Pämîrs, ${ }^{1}$ and some general Eranian peculiarities have been pointed out in $\S 36$, ante. Again we see points of agreement with the so-called 'Tuxāri, ${ }^{2}$ one of the newly discovered Central Asian languages, and J. Bloch ${ }^{3}$ has traced points of phonetic connexion between them and the dialect of the Dutreuil de Rhins fragments. Al] indications, therefore, point to a relationship with the Aryan languages spoken beyond the Hindūkush-Eranian or Semi-Eranian-or possibly even with the "North Aryan" language of Professor Leumann. One important point of agreement with the Shāhbāzgarhi dialect is the fact that consonants which in Prakrit are doubled, are not doubled in Modern Pisáca. Thus, the representative of the Sanskrit śabda- is Kâšmini sada-, not sadda-, as it would be in the Prakrits of India proper. It is well known that the same is the case in Shāhbāzgarhi and Mansehrā although every scholar that has hitherto written regarding these inscriptions has assumed that the non-doubling is due to a supposed imperfection of the Kharōsthi alphabet, ${ }^{4}$ and has taken upon himself to supply the doubled consonants on the analogy of the Prakrits just mentioned. I venture to consider this to be a mistake. The character could have represented double consonants, had the writer desired it, just as it successfully represented other consonantal combinations, and it is a dangerous act to assume their existence when the modern languages of the same tract do not know them. ${ }^{5}$ Reference has already been made to the possibility that Māgadhì Prakrit had a common origin, not only with the ancestor of North-Western Indo-Aryan Vernaculars but also with the ancestor of Modern Piśáca (ante $§ \S 50,51$ ), and I do not refer to the subject again.

80. In dealing with the Indo-Aryan Vernaculars we shall naturally compare them in the following pages with the Secondary Prakrits from which they are derived, and not directly with Sanskrit. The relationship between Sanskrit and Prakrit will nowhere immediately concern us. That has been completely

${ }^{1}$ e.g. Khō-wār ispa, Waxī spā, our.

2 Grierson, "Étymologies Tokhariennes" : Journal Asiatique, 1912, 339.

3 "Le Dialecte des Fragments Dutreuil de Rhins": Journal Asiatique, $1912,331$.

4 It is of course well known that other compound consonants occur in Kharōṣthĭ.

' Cf. Grierson, JRAS. 1913, $141 \mathrm{ff}$, for many other examples. 
discussed in Pischel's Prakrit Grammar, a work with which the reader will throughout be assumed to be familiar. But in regard to the Modern Pisáca languages, we have no Prakrit to which we can immediately refer them, or, at least, the materials available from the Paiśāci Prakrit are too scanty to do more than to suggest lines of inquiry, instead of giving certain proof. We shall, therefore, as a rule be compelled to compare Modern Piśāca directly with the Primary Prakrit, of which Sanskrit is the only literary form that we possess, or with the language of the Avesta in regard to points of contact with Eranian.

\section{APPENDIX TO CHAPTER II}

Connexion between North-Western Indo-Aryan Vernacular and Eastern Indo-Aryan Vernacular. See $§ 52, n .1$.

81. As Hoernle has already shown the close connexion between Marăthī and East Indo-Aryan Vernaculars, and the point requires no proof, I do not refer to it here, and shall as a rule confine myself to North-Western and Eastern Indo-Aryan Vernaculars, only citing Marāthì and the Intermediate Vernacular when necessary for illustration. As Kāśmiri, although a Modern Piśáca language, often shows clear relationship to the NorthWestern Indo-Aryan Vernaculars, I shall also occasionally quote it.

82. Phonetics.-In Kāšmīrī and Sindhīi, a final short $i$ or $e$ are very slightly pronounced, so as to be hardly audible. ${ }^{1}$ The same is the case in Bihārī. Thus Kš̀. ach ${ }^{i}$, S. alchi, an eye; S. $a \dot{n} \bar{a} r^{u}$, charcoal; Bihārī ã $k h^{i}$, an eye ; à்gōr (for $a \dot{n} g \bar{a} r^{u}$, with epenthesis), charcoal; dèkhathu, let him see.

83. As in Bihäri $a \dot{n} g \bar{o} r$ above, this very short final vowel is often elided, but epenthetically affects preceding vowels, especially in Lahndā. Thus, Lahndā vähir, a heifer, for ${ }^{*} v \bar{a} h a r^{i}$; våhur, a bull-calf, for *vāharu, and many others. ${ }^{2}$ So in Bengali and Oriya $\bar{a}$ there are words like baggun, the egg-plant, for *vangan ${ }^{*}$, $\bar{a} g u n$, fire, for ${ }^{*} a g a n^{u}$.

84. All over the north-west, it is well known that $e$ is frequently confounded with $i$, and $o$ with $u$. Thus Sindhì iharō, pronounced eharo, such; mihiti, pronounced mehete, a mosque, $\bar{g} \bar{a} l^{i}$, pronounced $\bar{g} \bar{a} l^{e}$, a word; ukhiri, a mortar, but Prakrit

1 So also in Dravidian languages.

2 This is also common in Kăšmirī, but the final short vowel is also preserved. 
*olkhaliā. So, in Bihāri we have both $u k^{a} r \bar{a}$ and okara him, and many similar forms. In Assamese $\tilde{o}$ is always pronounced $u$; thus $\tilde{\partial} t h$, a lip, pronounced $\tilde{u} t h$. Even an original $u$ is written $\bar{o}$, as in $\overline{o p a j} \bar{a}$, begotten, pronounced upa $\check{z} \bar{a}$.

85. The change of $u$ to $i$ is common in Sindhi and the Eastern Indo-Aryan Vernaculars, but rare in the Midland. Thus, S. mukitu (mukutam), a crown; kutimu (kutumbah), a family; Sindhī $b \bar{a} r \bar{\imath}$, Bengali, Oriyā, Assamese, $b \bar{a} l \bar{c}$, sand (Prakrit vāaluā); Bengali tanik, a little for Apabhrạ̣śa Māgadhī Prakrit *tanulkki; Apabhramśa undaru or unduru, Eastern Indo-Aryan Vernacular indir, Marāthī undir, but Rājasthānī ũdarō, a rat.

86. All over the north-west and also in Gujarātī and Rājasthānī, the diphthong $a i$ (derived from $a \ddot{i}$, not the Sanskrit $\overline{a \imath}$ ) shows a tendency to became $\ddot{a}, \bar{e}$, or even $\breve{a}$ like the $\breve{a}$ in the German "Mann". This also occurs in special cases in Hindi, but in the above localities it is universal. Thus the Hindi mai, I, is

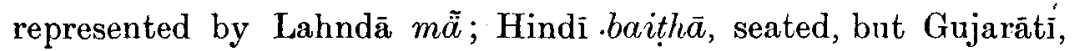
Rājasthānì bẹthōo ; W. Rājasthānī mă, written mai, in ; Sindhī bëru, the jujube, Prakrit vaïrō. A similar change, but rarer, occurs in Eastern Indo-Aryan Vernaculars, as in Bihārī mẽe, I ; bēr, a jujube.

Again $a u$ (for $a \ddot{u}$ ) in the same tracts becomes $a$ or $\bar{o}$. Thus Hindì kaun, Gujarātī kån (LSI, IX, ii, 345, and R. G. Bhandarkar,

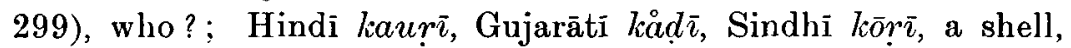
Lahnda $k \hat{o} r \bar{\imath} \bar{c}$, a kind of wart; Cf. the Bengali termination $\bar{o}$, written $a$, as in $b h \bar{a} l a$ (pronounced $b h \bar{a} l \bar{o}$ ), good. In Assamese every $a u$ or $\overline{a u}$ is pronounced $\bar{o}$. Thus $\bar{a} \bar{u} s \underline{a} \alpha h$, medicine, is pronounced $\bar{o} \chi \breve{o} d h$.

87. Although neither Lahnda nor Sindhi have the sounds, the neighbouring languages of the north-west, especially the Eranian Pašsto, and the Modern Piśāca Käšmiri frequently change $c$ to $t$, and $j$ to $z$ or $\underline{d z}$. Thus Pašto tsäri , Sindhi cārī, a spy ; Paštō $d z \bar{o} l \bar{\imath}$, Sindhī $j h \bar{l} \bar{\imath}$, a wallet; Kāšminì tsalun, to flee, Sindhì calañu, to depart; Kš. $z \bar{a} n u n$, S. $\bar{\jmath} \bar{a} n a n^{u}$, to know. A similar change occurs as is well known in Maräthi. In Assamese $c$, and in Bengali $c h$ (so also dialectic Marāthì) are pronounced $s$, and in vulgar Bihārì and Bengali $j$ is regularly pronounced $z$, and in Assamese as $\check{z}(=z h)$.

88. Lahndā and Sindhī (like Kāśmìri) have the palatal $\tilde{n}$. It also reappears in Eastern Indo-Aryan Vernaculars. Thus Assamese gos $\bar{a} i \tilde{n}(g u \chi \bar{a} i \bar{n})$, a religious teacher; Bihärī thāañ or thāi $i \tilde{n}$, but Hindi thẫw, a place. 
89. Sindhi prefers the dental $r$ to the cerebral $r$, and frequently derives it from $l$ (Trumpp, Gr. xxix ; Hoernle, Gḍ. Gr., $\S$ 16). So also the Eastern Indo-Aryan Vernaculars. Thus Hindī siāl, Sindhī siā $r^{u}$, Bihārĩ siār, a jackal. In Bihārì rustics are almost unable to distinguish between $r$ and $l$, and in Bengali the change is very common.

90. It is well known that in North-Western Indo-Aryan Vernaculars and in Modern Piśáca languages, the cerebral and dental letters are frequently confounded. It was the same in Vrācaḍa (Pischel, Pr. Gr., § 28). In the Thaḷi dialect of Lahndā, $d$ regularly becomes $d$. This also is the case in the East. Thus

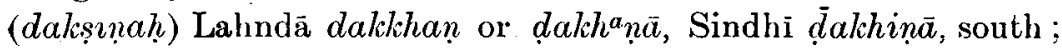

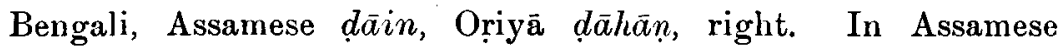
cerebrals and dentals are often confounded in pronunciation (Brown, A. Gr., 9).

91. Kāśmìì, under the influence of a neighbouring palatal sound, frequently changes $d$ to $j$, and $d$ to $z$. With this cf. Maräthī $n \bar{q} j<n i d r \bar{a}$, sleep; Sindhī $\bar{g} i j h^{u}$ (grdhrah), a vulture ; Prakrit $d h \bar{\imath} \bar{a}$, Bengali $j h \bar{\imath}$, Oriya $\bar{a} j h i \bar{a}$, Assamese $j \bar{\imath}$, a daughter.

92. In North-Western and Eastern Indo-Aryan Vernaculars $m b$ becomes $m$ or $m m$, while in Hindi it becomes $-b$. Thus

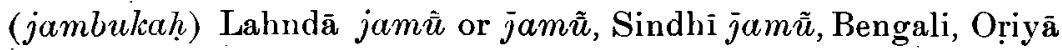
jām, but Hindì jâa $b \bar{u}$; (nimbah̆) Lahndā nim, Sindhī nim ${ }^{u}$, Bihārīi, Bengali, Oṛiyā nìm, Assamese nim, but Hindī nĩ̂b; (lambah) Lahndā lammāa, Bihārī lāmāa, Bengali lām, but Hindi lambā, long, and many others. Cf. Hoernle, Gạ. Gr., 20. In the same section Hoernle points out that the development of $y$ in the north-west is the same as in Eastern Indo-Aryan Vernaculars.

93. In Kāšmini and all the Modern Piśāca languages a medial $r$ is very frequently elided (Grierson, Piśăca Languages, 122). This has not been specially noted in the North-West, but is very common in colloquial Eastern Indo-Aryan Vernaculars, e.g. Bihārī kai for kari, having done; Coll. Bengali mailām for marilām, I died.

94. The change of $s$ or $s$ to $h$ is one of the typical peculiarities of the North-West. Examples are (busam) Sindhi buhu, chaff; (upaviśati, uvaisai) Sindhi bihe, he sits. The same change is common not only in Modern Piśäca languages, but also in vulgar Gujarāti, as in hamajavu for samajave, to understand, etc. Except in sporadic instances, we do not meet this again till we 
reach Eastern Indo-Aryan Vernaculars. 'Thus, (paśuḥ) Bihärī pōhēe, cattle; (gōśălam) Bihärì gōhāl, a cowhouse. In Assamese it compounded $s$ and $s$ always become a roiceless guttural spirant, transliterated by $\chi$; thus $\chi^{\bar{a} s t r a}$ for sasstra, scripture; $\chi a$, for $s \boldsymbol{a}$, a hundred; $\chi a \dot{n} g r \bar{a} m$ for sangrām, a fight.

95. While Hindi has only a dental $s$, those Outer Indo-Aryan Vernaculars that do not change $s$ to $h$ often change an original $s$ to $s$. In Maratthi $s$ is used before palatal vowels and $s$ before non-palatals, irrespective of derivation. In Bihārí $s$ is always written, and $s$ is always pronounced. In Bengali and Oriyāevery sibilant becomes $s$ in pronunciation. With this may be compared the changes that sibilants (compounded and uncompounded) undergo in Māgadhi Prakrit. We thus see that while Hindi prefers a dental $s$ all Outer Indo-Aryan Vernaculars treat sibilants with great freedom.

96. In all Outer Indo-Aryan Vernaculars there is a strong tendency to omit aspiration. In Modern Piśáca languages all 'sonant aspirates are disaspirated (cf. § 352). So Dẹrāwāl Lahndā gidda for ghidda, taken as if from. ${ }^{*} g r d d h a h$ in the sense of

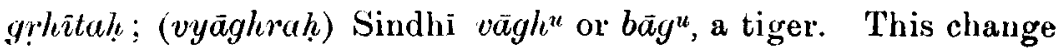
occur's sporadically in all Indo-Aryan languages. $J h$ becomes $j$ or $z$ in Assamese, as in Bengali $j h \bar{\imath}$, Assamese $j \bar{\imath}(z \bar{\imath})$, a daughter. So Hindi jhāl, pungency, but Assamese $j \bar{a} l$ (zăl); Hindi bujh-, extinguish, but Bengali, Marāṭhì, Gujarâtī, Rājasthāni buj-; Bengali, Marāṭhi, Gujarāti sấjh or säj, evening. We thus see that the disaspiration of this sonant occurs only in Outer and Intermediate Indo-Aryan Vernaculars.

Similarly for $d h$. Hindi paṛt-, Bengali pa?-, read; Hindi cạ̣h-, Bengali, Rājasthänì ca?̣-, mount; Hindì kōrhl, leprosy,

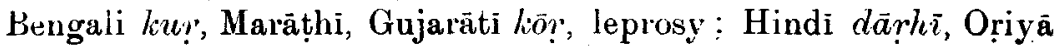
dàdi, Bengali dārī, a beard.

$D h$ is often disaspirated in Rājasthāni, as $b \hat{\bar{a}} d-$, bind; $\bar{a} d \bar{o}$, half; $l \bar{a} d$-, get: $d \bar{u} d$, milk. So Kâšmirì $d \breve{o} d$, Bengali dud, ınilk; Marâthī, Gujarātĩ gid, a vulture; Sindhì dlù $h \hat{o}$, smoke.

For $b h$ we have Sindhi $b \bar{\imath} k h^{a}$, alıns ; $b u k h^{a}$, hunger ; Rājasthāni $b h \bar{\imath}$ or $b \bar{\imath}$, also; Dẹrāâal Lahndā bai, a brother; Hindi jībl, but Assamese $j i b \bar{a}$, the tongue.

T'urning to the surd aspirates, $k h$ is usually preserved, except in Marạthi, and occasionally in the other Outer Indo-Aryan Vernaculars. Thus, M. sil-, learn; bhuk, hunger, and others. 


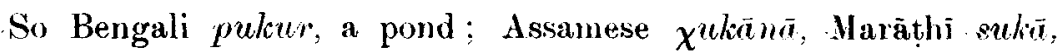
Sindhi sukō, Jahndā sukeā, dry.

As for ch, in Assamese it always becomes" (pronounced $s$ ), is in $m \bar{a} c$ ( $m \bar{a} s)$, a tish. So also Oṛiyă kācim, a tortoise ; Rājasthāni cip-, for chip-, conceal. Elsewhere the aspiration is generally preserved.

Th is disaspirated only in Bengali lintātie an axe: pit, the back, etc.

Th is disaspirated only in a ferv words, the most important of which is Rājasthāni, Marāthì, Bengali, Assamese, Oriyà hōt: others häth, a hand.

$P h$ is also rarely disaspirated. We have Bengali, Assamese, Oriyā bhāp, vapour; Assamese pelitēe, Bengali phelite, to throw.

From the above we see that disaspiration is contined to Outer and Intermediate Indo-Aryan Vernaculars. That of surd consonants is chiefly confined to the south and east, while that of sonants is also common in the north-west.

97. Sindhī, Lahndā, and Modern Piśáca Languages avoid doubling a consonant, and where Prakrit has a double consonant they have a single one, without compensatory lengthening of the preceding vowel. This is also common in the Outer and Intermediate Indo-Aryan Vernaculars, but does not occur in the Midland. Thus, Sindhī $c c k^{u}$, Oriyā $c a k$, a wheel. Elsewhere ralk, $c \bar{a} k$, etc. There are hundreds of other examples. To quote only a few, Hindi $m \tilde{a} g$-, Sindhi $m a \dot{u}$, ask; Hindi sūkha $\bar{a}$, Kāšmiri

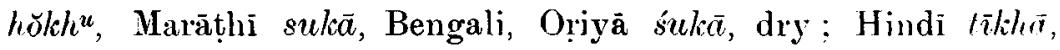
Assamese tikhā, sharp; Hindi sãc or sacc, Sindhi sactu, Assamese sãca, true; Hindi süjh-, Sindhi sijh-, Marāthì sijj, Gujarătì, Bengali, Oriyā, Assamese sij-, be stewed; Hindi jüjh-, Maräthi jhujh-, be killed in battle; Hindi müthì, Sindhi mutthe, Assamese muthi, a fist; Hindi kã $a$, Lahndā, Kāšmīrĩ kan, Sindhì lianu, an ear ; Hindì pāu, Lahndā panãa, Kāšmìrì pan, Sindhì pun $p^{u}$, a leaf : Hindī bhàt, Lahndā bhat, Sindhī bhatu, Kāšmirī bata, boiled rice; Hindì rassī, Sindhī, Gujarātî, Bengali, Oriyā rasī, a string ;

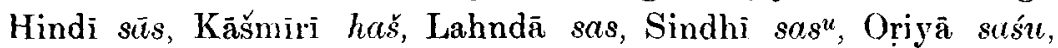
a mother-in-law; and many other's.

98. Declension and Conjugation.-Nouns, which in Sanskit and Prakrit form their feminines in $\bar{a}$, in the North-West often form them in $i$ or $e$. Thus, Sanskrit vărttā, news, Sindhī bāte. So also in Bihārì, the feminine of the Tatsama atyant, excessive, 
is atyandi, although in Sanskrit it is atyanta. 'This is the regular rule in Bihärī (Maithili).

In the North-West certain genitive postpositions are derived from the present participle of the verb substantive. Thus, Käsmiri handu, Sindhi sandō. So also Western Rājasthāni handō. In Bengali the same participle, haïte, is employed to form the postposition of the ablative. It is not used elsewhere in this way.

In Hindi, the only relics of synthetic declension are the oblique cases singular and plural and a rare locative in $\bar{e}$, as in ghare ghare, in each house. In all the Outer Indo-Aryan Vernaculars and in Käśmiri there is, on the contrary, alongside of the analytical, a respectable synthetic declension. We shall discuss only the singular number, as that is sufficient for our present purposes. In Käšmiri there is a dative ending in $s$, as in Marāthi, an agent case, and an ablative, all formed synthetically. Thus, tsurr, a thief; tsuras, to a thief; tsuran, by a thief; and taure, from a thief. For $i$-bases, it has guru, a horse; guris: yuri ; and gurvi. The ablative is also used as an oblique case. Sindhi has discarded part of this, but it still has the locative, and the agent and the oblique case. Thus, jhang" ; a forest; loc. jharige, ag. and obl. jhang ${ }^{a}$. Jahnda elosely follows Sindhi, but the declension is obscured by epenthesis. Thus, jangitl (for juigal ${ }^{u}$ ), a forest; loc. jangil (for janguli); ag. and obl.jangal. (for jangul"). The Southern Indo-Aryan Vernacular, Marāthì, has also a synthetic declension, forning its dative in $s$, an agent case in $\tilde{e}$, and a locative in $\bar{b}$, in addition to the oblique case. Thus, ghar, a house, dat. gharās, ag. gharè, loc. gharĩ, obl. ghara $\bar{a}$. In Eastern Indo-Aryan Vernacular, Bihāri has a synthetic agent and locative, and the genitive is also becoming synthetic. Thus, from ghar, ag. gharễ, loc. ghare, gen. ghar-lier (analytic) or gharak (synthetic). Bengali has a synthetic ag. gluare, gen. ghecre $e^{r}$, and loc. ghare. There is also a synthetic instrumental as in churite, by a knife (churi). Assamese and Oriyā are very similar. We thus see that all the Outer Indo-Aryan Vernacular have synthetic methods of declension that are quite wanting in the Midland.

99. In North-Western Indo-Aryan Vernaculars and Kāšmiri pronominal suffixes are very common, but are unknown in the Midland proper. Thus, Lahndā ghar-ame, my house; ghar-us, his house; Sindhi piume, my father; piuse, his father. These 
have fallen into disuse with nouns substantive in the other Outer Indo-Aryan Vernaculars, except in distant Assamese, where they have been kept alive by the example of Tibeto-Burman pronominal prefixes (see $\$ 75$ ante). Thus, Assamese bāp, a father; $b \bar{o} p \bar{a} i$, my father; bāpek, his father. Rājasthāni has also preserved the pronominal suffix of the third person $(k)$ as a pleonastic suffix, as in katarō or katarō-k, how much? (LSI. IX, ii, 35).

The use of pronominal suffixes with verbs has been preserved throughout all the Onter Indo-Aryan Vernaculars, and forms a prominent feature of conjugation, while it is entirely wanting in the Midland. It also exists in Rājasthãni and Eastern Hindi. It is unnecessary to give examples of this here, as to do so would only be repeating the chapter on verbs later on in this book. Suffice it to say that the conjugation of nearly all the tenses of the Outer Indo-Aryan Vernacular verb is synthetic, and is in most cases modern in origin, being formed by the accretion of pronominal suffixes. On the contrary, in the Inner languages, the only synthetic tenses are the two or three which have survived from Prakrit, and these also are found in Outer IndoAryan Vernacular.

The modern origin of the Outer Indo-Aryan Vernacular synthetic conjugation is well shown by the languages of the north-west. Thus:-

\section{Analytic}

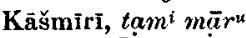

Lahndā, $\overline{\bar{u}} m \bar{a} r e \dot{a}$

Sindhī, hun ${ }^{a}$ mãriōo

Rājasthānī, wō māryō

Eastern Hindĩ ---

Bihārī

Benguli

Assamese

Oriyā and Maräțhì

But Hindî, us-nè märă.

$$
\text { "He struck" }
$$

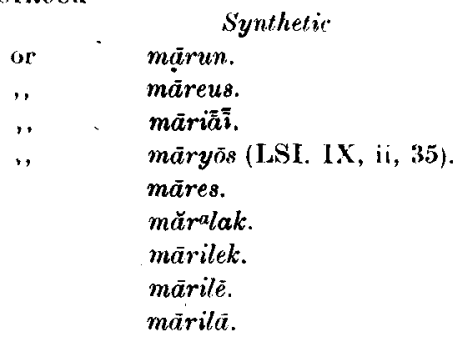

A form of the Past Participle, of which the characteristic letter is $l$, occurs in Modern Piśāca, North-West, South, and Eastern Indo-Aryan Vernaculars, but not in the Midland. Thus Modern Piśáca (Maiyã) kuṭ-ag-il, Sindhī māoia-lu, Gujarātī $m \bar{a} r \bar{e}-l \bar{o}$, Marāṭhi, Oṛiyā märi-lāt, Bihārī mär-al, Bengali, Assamese $m \bar{a} r$-il, struck. There is no similar form in Hindi or Eastern Hindi. 
100. As regards vocabulary one word may be mentioned which shows the relationship between the Eastem and NorthWest Indo-Aryan Vernaculars in a striking manner. According to Hc. iv, 294, the Magadhi Prakrit equivalent of the Sanskrit rajati, he goes, is vañnadi. The Măhăansțí Prakrit form is

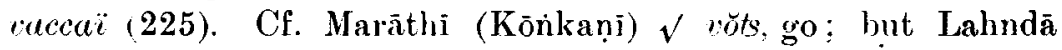
$\checkmark$ vañ, go.

101. It will, therefore, have been seen that in many crrammatical features, the North-Western Indo-Aryan Vernaculars are connected with the Southern and the Eastern Indo-Aryan Vernaculars, and agree with them in presenting the same contrasts to the Midland languages. That the North-Western languages in many respects occupy an independent position cannot be denied, and this is largely due to the influence of the neighbouring Modern Piśāca languages. Whether there was an original relationship between these two, as Hoernle suggests, it is at present impossible to say. They have many points in common, but also many points of difference. Whether the former are due to a common origin or to mutual borrowing I do not ventwe to say, but on the whole $I$ at present incline to the latter opinion (soe $\$ 51$, ante). 